\title{
Who are Non-Resident Fathers?: A British Socio-Demographic Profile
}

\section{ELOISE POOLE*, SVETLANA SPEIGHT ${ }^{* *}$, MARGARET O'BRIEN***, SARA CON NOLLY**** AND MATTHEW ALDRICH*****}

\author{
*Arts Council England, Policy and Research Team, The Hive, Lever Street, Manchester, M1 \\ 1FN email: eloise.poole@googlemail.com \\ ** Policy Research Centre, NatCen Social Research, 35 Northampton Square, London EC1V \\ OAX, UK email: svetlana.speight@natcen.ac.uk \\ *** Thomas Coram Research Unit, UCL Institute of Education, University College London, 20 \\ Bedford Way, London WC1H OAL, UK email: m.obrien@ioe.ac.uk \\ ****Norwich Business School, University of East Anglia, Norwich NR4 7JT, UK \\ email: sara.connolly@uea.ac.uk \\ ***** School of Economics, University of East Anglia, Norwich NR4 7JT, UK \\ email: matthew.aldrich@uea.ac.uk
}

\begin{abstract}
Despite international growth of, and policy interest in, divorce and separation since the 1970s, there is still surprisingly little known about non-residential fatherhood. This paper presents a 'father-centric' analysis and provides one of the first profiles of non-residential fatherhood in early millennium UK. Using data from Understanding Society Wave 1 , a nationally representative survey of over 30,0oo households in the UK, we found 1,07o men self-identifying as having a non-resident child under 16 years old (https://www.understandingsociety.ac.uk). We estimate a prevalence of 5 per cent of British men having a non-resident dependent child. Through latent class analysis, four distinct groups of non-resident fathers are identified: 'Engaged' fathers, 'Less Engaged' fathers, 'Disengaged' fathers and 'Distance' fathers. Our analysis finds that non-resident fathers form a heterogeneous group in terms of their sociodemographic profile and family behaviour. It is recommended that legislation and policy concerning fathers in post-separation families are sensitive to variation as well as commonality in socio-economic conditions and family lives and situations.
\end{abstract}

\section{Introduction}

Over the last four decades family forms have been changing across the world. In Western and high-income countries this is partially a consequence of increased relationship dissolution and subsequent remarriage and re-partnering (Organisation for Economic Cooperation and Development, 2010). In the UK there are estimated to be four million dependent children living in two and a half million separated families (Department for Work and Pensions, 2012). Government estimates indicate that the vast majority, around 97 per cent, of separated parents with primary care of children are mothers (Department for 
Work and Pensions, 2010). Given the increase in parental separation, it is probable that there are a growing number of non-resident fathers in the UK. However, despite this social change and increased interest in both resident and non-resident fathers (Kiernan, 2006; Haux et al., 2015), data on fathers are not systematically collected resulting in an acknowledged evidence gap relating to fathers in general and non-resident fathers specifically (Cabrera and Tamis-LeMonda, 2013).

The policy and legal landscape, regarding separating and separated families, is currently undergoing substantial changes in the UK and some other countries. At the same time, the UK is implementing a wide-ranging welfare reform, which could have direct relevance to fathers living away from their children. It is important that these legal and policy changes draw on up-to-date, nationally representative evidence regarding the lives and situations of non-resident fathers in the UK. What are the socio-economic and family circumstances of nonresident fathers in the UK? Which factors are associated with less regular contact between non-resident fathers and their children, and thus have the potential to affect, negatively, outcomes for these children? Our research aims to provide an evidence base for fathers' post-separation parenting, drawing on data from fathers themselves, and to set out a context for future policy development.

Our research is novel in providing a 'father-centric' study and an up-to-date representative profile of non-resident fathers in the UK. For this analysis, we use the longitudinal panel survey Understanding Society (Wave 1, 2009-2011). As information is collected from each household adult member individually, this survey has the unusual benefit of providing data from the perspective of the non-resident father (while most other research about non-resident fathers relies on information collected from mothers, see below). Furthermore, our research provides a UK-based analysis, a benefit when the majority of research literature in this area comes from the US.

Following an outline of the existing literature and of the changing policy and legal context, we provide a brief profile of non-resident fathers in the UK at the start of the 2010s. We examine the range of care and contact arrangements which non-resident fathers report they have with their children, and the characteristics associated with care and contact. Further, we cluster non-resident fathers into four groups based on the involvement they have with their non-resident children and their current family situation. Finally, we draw out conclusions from our analysis and discuss implications of policy changes in the UK for these four non-resident father groups.

\section{Non-residential fatherhood: partnership and parenting}

The demography of non-resident fatherhood and of fatherhood more generally is still in its infancy (Cabrera and Tamis-LeMonda, 2013). However, scholarship is 
beginning to chart men's family and household formation. Recent analysis points to a steady decline of father-child co-residence among men born between 1930 and 1979 in England and Wales (Henz, 2014). The evidence gap is exacerbated for nonresident fathers who are a hard to reach group; unlike lone mothers they cannot be identified through government records. Representative primary research with non-resident fathers is limited (Hernandez and Brandon, 2002) leading to the use of proxies to quantify and investigate the population, for example rates of lone motherhood are often used as a proxy for rates of non-resident fatherhood (OECD, 2010; O'Brien, 2011). Similarly data about non-residential fathers' family relationships are often gathered from other family members, notably the resident parent of their children. While such data provide important insights into post-separation parenting, it cannot comprehensively capture paternal perspectives. Notwithstanding these problems, a body of literature is developing on the socio-economic well-being of non-resident fathers, though the majority of evidence comes from studies conducted in the US (Scott et al., 2013).

The first wave of British empirical research on non-residential fatherhood, or 'absent fatherhood' as it was sometimes labelled, began in the $1990 \mathrm{os}$ in the wake of the rapid rise in divorce and lone parenthood during the previous decade and the formation of the Child Support Agency in 1991 (Simpson et al., 1995; Maclean and Eekelaar, 1997; Bradshaw et al., 1999). Most studies were small scale providing rich qualitative data on the family and social lives of men living apart from their children, depicting how they managed, and in many cases struggled, to keep positive relationships with children and ex-partners. Bradshaw et al.'s (1999) study suggested that non-resident fathers were a more disadvantaged group than other fathers, both financially and in terms of general well-being. These findings were further reinforced by the US literature. For example, when compared with continuously married men, American divorced men tend to report lower household incomes and household wealth (Zhang and Hayward, 2006) and poorer physical and emotional well-being (Eggebeen and Knoester, 2001).

Subsequent British analysis using cohort studies such as the National Child Development Study (University of London, 1974) and the Millennium Cohort Study (University of London, 2012) (Kiernan, 1997; Kiernan and Smith, 2003; Kiernan, 2006), although not based on direct data from non-resident fathers, has provided insights into their prevalence and characteristics, particularly at the child's birth. For instance, Kiernan and Smith (2003) reported that 15 per cent of mothers were not in a co-residential partnership at the birth of their children. However, about a half of these mothers reported being 'closely involved' with the father. This suggests a 'complexity and fuzziness of parental relationships' (Kiernan and Smith, 2003: 33) which is crucial to an understanding of nonresidential fatherhood. 
Similarly, there are pervasive challenges to understanding the characteristics and quality of non-residential fathers' relationships with their non-resident children, as most models of father involvement have a resident father template (Cabrera and Tamis-LeMonda, 2013). The classic concept of father involvement (Lamb et al., 1985), of engagement, accessibility and responsibility tends to foreground caretaking and shared activities with the child involving direct contact. Accordingly most studies of non-resident fathers have focused on their frequency of contact with children. This research suggests that, despite alarmist headlines to the contrary ${ }^{1}$, there has actually been a reduction in the proportion of cases where fathers cease to have any contact with their non-resident children following separation, at least in the US (Amato et al., 2009). Instead a notable pattern of diversity in the quantity and quality of contact and care that nonresident fathers have with their children is emerging (Cheadle et al., 2010). British evidence, pooling maternal accounts from five waves of the Millennium Cohort Study, shows that loss of father-child contact was not a dominant pattern; at least 8 out of 10 children were in contact with their non-resident father (Haux et al., 2015).

A range of factors, related to the extent of contact and involvement which fathers have with their non-resident children, has been identified, although the majority of this evidence is drawn from studies conducted in the US (see Amato and Dorius, 2010 for a comprehensive overview). These factors broadly relate to the non-resident father's own characteristics, the characteristics of the resident mother, child characteristics, relationships formed before and after separation, and practical considerations.

With regard to the fathers' socio-demographic profile, age (Manning et al., 2003), education (Cheadle et al., 2010) and income (Swiss and Le Bourdais, 2009, Haux et al., 2015) have been found to be positively associated with contact in North-American and recent UK studies. Compared with fathers who were never married to the mother, divorced fathers tend to have more contact with their non-resident children (Amato et al., 2009). Fathers' religiosity has been found to be associated with contact (King, 2003). However findings relating to race and ethnicity are not consistent and Amato and Dorius (2010) have noted that this probably reflects a complex mix and interaction of cultural, structural and economic factors in the US.

Unsurprisingly, where the father has a cooperative relationship with the mother post separation they are more likely to be in contact with their nonresident children (Sobolewski and King, 2005). Additionally, some studies have found associations between contact and child characteristics such as age (Haux et al., 2015) and gender (Hetherington, 2003, Haux et al., 2015), although the research findings in this area are not consistent.

New relationships, both the father's and the mother's, are associated with contact between non-resident fathers and children. Several North-American 
studies have shown that, after parents remarry or form new cohabiting relationships, non-resident fathers have less contact with their children (Stephens, 1996, Swiss and Le Bourdais, 2009). There is also a negative association between having new children and contact with non-resident children from previous relationships (Manning et al., 2003). It is noted that this is likely to be related to the fact that new commitments and new unions create demands and consume financial, time and other resources which then cannot be spent on non-resident children.

Two other factors have been consistently associated with contact: geographical distance and payment of child support. The further away a nonresident father lives from his children, the less frequently he is in contact. This could be related to the fact that, when the child moves away, there is a financial and time disincentive to maintaining contact but also that fathers who already have weak commitments to their children will feel less constrained in moving away despite the barriers to contact this creates (Cheadle et al., 2010, Bradshaw et al., 1999). There is a well-established positive association between contact and the payment of financial support for children (Amato et al., 2009; Cheadle et al., 2010). However the direction of the association is not known and the association may not be completely straightforward: a UK study shows that when contact reaches a high frequency financial support can decrease, being replaced by other forms of support or deemed unnecessary (Morris, 2007).

Finally, it is important to note that conceptualising and measuring men's caring in families is connected to societal cultural norms about what constitutes 'the good father'. As Skinner (2013: 262) argues, 'norms of fatherhood may not necessarily operate exactly the same way in the context of non-residential fatherhood'. At the same time, non-resident fathers may still be characterised as 'dead-beat' or 'feckless fathers' by virtue of not living with their children. Such views are reinforced by media coverage of reports such as the UK report Fractured Families (Centre for Social Justice, 2013) where the media stressed just one dimension, children growing up in 'man deserts', even though the report was more wide-ranging.

\section{The changing legal and policy context for separating and separated parents}

In England and Wales both parents have parental responsibility for their dependent children and this remains in place following separation, regardless of the residential situation of the child. Post-separation parents are expected to make care and financial arrangements for their children although, in practice, the vast majority of children reside for the majority of the time with one parent, usually the mother, and have contact or residence with the other parent, usually the father, for less time. 
In most situations parents decide the care and contact arrangements for children privately, with the court only being involved in around 10 per cent of cases (Fehlberg et al., 2011). However, use of the statutory child maintenance ${ }^{2}$ service is more widespread; at the end of September 2014 the Child Support Agency (CSA) had a live caseload of 1.37 million families (Department for Work and Pensions, 2014). Since its introduction in 1993, the CSA has been the statutory service responsible for helping separated parents with their child maintenance arrangements, with the aim of ensuring that all non-resident parents provide a realistic and consistent amount of financial support towards the upkeep of their children. Despite a range of improvements introduced by the 2008 Labour government, the CSA was, for most of its existence, beset with major problems. These included technological issues exacerbated by IT problems and a complex maintenance formula, an overwhelming caseload resulting in errors and inaccuracies, and difficulties in contacting and maintaining records both for parents with care and non-resident parents (Bryson et al., 2013).

The legal and policy landscape for separated and separating parents is undergoing a number of changes. Taken together, these changes promote 'private' or 'family based' contact and financial arrangements for children, that is, arrangements which are agreed and enforced without the involvement of statutory services or the courts. The promotion of 'family based' arrangements is to be achieved through restricting access to legal redress and statutory services and the introduction and expansion of help and support services. The CSA is now subject to a rolling closure with all existing cases being closed and a new statutory service (Child Maintenance Service) established. Rather than making new statutory arrangements, separated parents are to be nudged towards making 'family based' child maintenance arrangements through the introduction of a gateway, application fees and ongoing fees for maintenance collection services. This policy turn, to a more private and individualist approach, is not new and started when the previous Labour government passed the 2008 Child Maintenance and Other Payments Act (Skinner, 2013).

With regard to access to legal services, the Ministry of Justice is undergoing large financial cuts and the scope of legal aid is being restricted so that it will no longer routinely cover family law. In practice this will mean that, unless there are exceptional circumstances, families and individuals without economic resources will no longer be eligible for financial support when undertaking legal redress in divorce, contact and shared parenting cases ${ }^{3}$.

Changes to the 'welfare of the child' principle included in the Children and Families Act 2014 reflect an aspiration for both parents to be involved in the care of children following separation. The previous legal position in England and Wales meant that, in disputes between parents, the court had to give paramount consideration to the welfare of the child. The amendments 
to the law include a presumption that, unless the contrary is shown, "[the] involvement of that parent in the life of the child concerned will further the child's welfare'. Furthermore, under the Help and Support for Separated Families (HSSF) initiative, the government has committed $\mathfrak{f}_{20}$ million to initiate out-ofcourt support for separated families.

A wide-ranging welfare reform started by the Coalition Government (20102015) and being continued by the current Conservative Government potentially puts additional pressures on non-resident fathers who are less financially well-off and, arguably, need additional support from the state. For example, the reduction of the Housing Benefit rate for under-occupancy (i.e., for a spare room in the house), referred to commonly as 'the bedroom tax', may discourage non-resident fathers from living in accommodation which would enable overnight stays from their non-resident children (Fatherhood Institute, 2013).

In order for policy changes to be effective, it is important to understand the population of separated parents. In profiling and investigating the current population of non-resident fathers in the UK and the relationships they have with their non-resident children, we make an important step towards enabling examination of how appropriate the policy changes are for different groups of non-resident fathers and which groups may require additional help and support.

\section{Methods}

The data presented come from the Understanding Society survey, Wave 1, collected between 2009-2011. Understanding Society is an annual UK-wide longitudinal household survey covering over 30,000 households. The survey interviews each adult household member aged $16+$ and collects data on a range of social, economic and attitudinal topics. Our analysis focuses on fathers who have non-resident children aged under 16 years old. In total, 1,070 fathers in Wave 1 identified themselves as having non-resident children aged under $16^{4}$ (see Appendix Figure $1 \mathrm{~A}$ for an overview of key measures used in the analysis).

Our analysis provides a cross-sectional profile and investigation of nonresident fatherhood. However, it does not present a longitudinal examination of non-resident fatherhood due to constraints on the number of non-resident fathers available in subsequent waves. Investigative analysis of Understanding Society Wave 3, which repeated the question on non-resident dependent children, showed that 66 per cent of the non-resident fathers identified at Wave 1 did not complete the questions at Wave 3. Given the small base size, and the fact that the remaining non-resident fathers were different in profile, we decided not to make any comparisons for this group of fathers over time. 
The types of data collected in the survey present further limitations. While we have data on men reporting having non-resident children and some information about their contact with these children (as reported by non-resident fathers themselves), we do not have data on the number and age of these children, on when the father became separated from them, or on variables concerning the resident mother and the relationship between the parents.

The measures relating to father involvement which are available in Wave 1 of the Understanding Society are not comprehensive and capture only some aspects of the classic concept of father involvement. We use data on frequency of contact between fathers and their non-resident children as an indicator of engagement (with the contact being worded in the questionnaire as 'visit, see or contact' and thus potentially covering face-to-face as well as phone/email/skype types of contact). Intensity of father-child engagement is captured through the variable of overnight stays. We also use data on fathers' self-reported provision of financial support for their non-resident children as an indicator of paternal responsibility. The advantage of this dataset is that these assessments of paternal involvement draw on fathers', rather than mothers', accounts and so complement other evidence on post-separation parenting.

We present findings from descriptive and binary logistic regression analyses 5 . The binary logistic model focuses on fathers of non-resident dependent children and compares fathers who have no or rare contact (defined as contact a few times a year) with those fathers who have more regular contact (from a few times a month to several times a week). The model was developed using variables which were significant in bivariate analyses ${ }^{6}$. The final specification includes only those explanatory variables which were statistically significant in binary logistic regression analysis and controls for father's age and educational attainment.

A typology of non-resident father types was constructed using latent class analysis (LCA $)^{7}$. LCA is a multivariate statistical approach used to categorise individuals into different groups or 'latent classes' according to their responses to a series of questions. The analysis was carried out in order to identify groups of non-resident fathers who had similar behaviour following separation. Drawing on previous literature, variables that were used in this analysis included the contact between father and non-residential children, distance lived from children, financial support and their family circumstances. A key aspect of LCA is identifying the number of latent classes that best fits the data. To do this we examined a range of models with different numbers of classes. There is no definitive method of determining the optimal number of classes. The four class model was chosen by examining measures of fit such as Akaike's Information Criterion (AIC) and the Bayesian Information Criterion (BIC) (Akaike, 1974; Schwarz, 1978), the probabilities of class membership, the principle of parsimony and, more informally, the interpretability of the model. 


\section{A profile of non-resident fathers in the UK}

As the Understanding Society survey interviews a representative sample of the UK population, we can use this data to provide a recent and accurate profile of non-resident fathers. Overall, 29 per cent of all men aged 16-64 in the UK report that they have dependent children, and 5 per cent of men report that they have non-resident dependent children $^{8}$. Using ONS population estimates (Office for National Statistics, 2013), this equates to 980,000 men in the UK, though this is likely to be an underestimate of the true figure as it only includes non-resident children aged under $16^{9}$. Furthermore, although Understanding Society gives the best current estimate of non-residential fatherhood in the UK, it relies on self-reporting of non-resident children. Other research has shown that men tend to under-report children who live elsewhere for a range of reasons including lack of knowledge, denial, unwillingness to acknowledge the children, attempts to hide the existence of non-resident children or a lack of relationship with non-resident children (Garfinkle et al., 1998; Rendall et al., 1999; Sorenson, 1997). However, it has been noted that, with the growth in family complexity and non-marital parenthood, the stigma against non-resident fathers has diminished and therefore self-reporting may increase (Stykes et al., 2013).

Although non-resident fathers are a diverse group, a range of characteristics have been found to be associated with non-resident fathers in comparison with resident fathers. Table 1 provides an overview of the characteristics of the three groups: fathers with only resident dependent children, fathers with only non-resident dependent children and fathers with both resident and nonresident dependent children. The differences between the three groups, in particular between those with and without non-resident children, fall into three main categories: relationship history, economic disadvantage and ethnicity and religion $^{10}$.

Unsurprisingly those fathers who only have resident children are more likely than those with only non-resident children to be currently living with a partner. They are also less likely to have never been married and/or never cohabited. Notably we find that fathers who have non-resident children appear to be younger and more economically disadvantaged than fathers who only have resident children. They are less likely to have a university degree, less likely to be in full-time employment, less likely to be in a management or professional role and less likely to own a home. Interestingly fathers who have both resident and non-resident children share a somewhat similar economic profile to those fathers who only have non-resident children. In addition to economic disadvantage, fathers with nonresident children also have poorer general health than fathers with only resident children, and fathers with only non-resident children exhibit poorer mental health than other groups of fathers (as measured by GHQ caseness). Finally, there are some differences by ethnic background and religious affiliation, with fathers from Asian backgrounds and fathers reporting Christian or Muslim religious 
TABLE 1. Characteristics of resident and non-resident fathers: fathers with dependent age children $(\mathrm{N}=6,392)$

\begin{tabular}{|c|c|c|c|c|}
\hline & $\begin{array}{l}\text { Fathers with } \\
\text { resident } \\
\text { children only } \\
\%\end{array}$ & $\begin{array}{l}\text { Fathers with } \\
\text { non-resident } \\
\text { children only } \\
\%\end{array}$ & $\begin{array}{l}\text { Fathers with } \\
\text { resident and } \\
\text { non-resident } \\
\text { children } \\
\%\end{array}$ & $\begin{array}{l}\text { All fathers } \\
\%\end{array}$ \\
\hline \multicolumn{5}{|l|}{ Age of father } \\
\hline 16-24 years old & 2 & 8 & 2 & 3 \\
\hline 25-34 years old & 22 & 25 & 26 & 23 \\
\hline $35-44$ years old & 43 & 37 & 34 & 42 \\
\hline 45 years or more & 33 & 31 & 19 & 32 \\
\hline \multicolumn{5}{|l|}{ Educational attainment } \\
\hline Degree or higher & 39 & 29 & 21 & 36 \\
\hline A level & 9 & 9 & 8 & 9 \\
\hline GCSE/other & 36 & 43 & 46 & 37 \\
\hline None & 17 & 26 & 25 & 18 \\
\hline \multicolumn{5}{|l|}{ Employment status } \\
\hline Works full-time & 81 & 63 & 68 & 79 \\
\hline Works part-time & 5 & 5 & 7 & 5 \\
\hline Unemployed & 7 & 17 & 16 & 9 \\
\hline Economically inactive & 6 & 15 & 9 & 7 \\
\hline \multicolumn{5}{|l|}{ NSSEC } \\
\hline $\begin{array}{l}\text { Management/ } \\
\text { Professional }\end{array}$ & 43 & 25 & 25 & 40 \\
\hline Intermediate & 17 & 13 & 15 & 16 \\
\hline Routine & 26 & 31 & 35 & 27 \\
\hline Unknown & 14 & 31 & 25 & 17 \\
\hline \multicolumn{5}{|l|}{ Tenure } \\
\hline Mortgage/own outright & 74 & 49 & 49 & 70 \\
\hline Social rent & 13 & 23 & 28 & 15 \\
\hline Private rent & 12 & 26 & 22 & 14 \\
\hline Other & 1 & 3 & 1 & 1 \\
\hline \multicolumn{5}{|l|}{ Ethnicity } \\
\hline White - British & 81 & 84 & 89 & 82 \\
\hline White-other & 5 & 5 & 4 & 5 \\
\hline Mixed & 1 & 1 & 1 & 1 \\
\hline Asian & 9 & 4 & 2 & 8 \\
\hline Black & 3 & 4 & 3 & 3 \\
\hline Other & 2 & 1 & 1 & 2 \\
\hline Unknown & $>0.5$ & $>0.5$ & $>0.5$ & $>0.5$ \\
\hline \multicolumn{5}{|l|}{ Religious affiliation } \\
\hline No religion & 54 & 64 & 68 & 56 \\
\hline $\begin{array}{l}\text { Christian (including } \\
\text { Catholic) }\end{array}$ & 36 & 31 & 29 & 35 \\
\hline Islam/Muslim & 6 & 2 & 2 & 5 \\
\hline Hindu & 2 & $>0.5$ & $>0.5$ & 1 \\
\hline Sikh & 1 & 1 & $>0.5$ & 1 \\
\hline Other & 2 & 2 & 1 & 2 \\
\hline \multicolumn{5}{|l|}{ Residential status } \\
\hline Lives with partner & 97 & 34 & 93 & 90 \\
\hline $\begin{array}{l}\text { Does not live with } \\
\text { partner }\end{array}$ & 3 & 66 & 7 & 10 \\
\hline
\end{tabular}


TABLE 1. Continued.

\begin{tabular}{|c|c|c|c|c|}
\hline & $\begin{array}{l}\text { Fathers with } \\
\text { resident } \\
\text { children only } \\
\%\end{array}$ & $\begin{array}{l}\text { Fathers with } \\
\text { non-resident } \\
\text { children only } \\
\%\end{array}$ & $\begin{array}{l}\text { Fathers with } \\
\text { resident and } \\
\text { non-resident } \\
\text { children } \\
\%\end{array}$ & $\begin{array}{l}\text { All fathers } \\
\%\end{array}$ \\
\hline \multicolumn{5}{|l|}{ Number of marriages } \\
\hline Never married & 16 & 42 & 31 & 20 \\
\hline 1 marriage & 73 & 44 & 34 & 68 \\
\hline 2 or more marriages & 10 & 14 & 34 & 12 \\
\hline \multicolumn{5}{|l|}{ Number of cohabitations } \\
\hline No cohabitations & 70 & 42 & 33 & 65 \\
\hline 1 cohabitation & 21 & 28 & 31 & 22 \\
\hline 2 cohabitations & 6 & 15 & 22 & 8 \\
\hline $\begin{array}{l}3 \text { or more } \\
\text { cohabitations }\end{array}$ & 3 & 15 & 14 & 5 \\
\hline \multicolumn{5}{|c|}{ Number of children has ever had } \\
\hline 1 child & 25 & 36 & 1 & 25 \\
\hline 2 children & 41 & 36 & 22 & 40 \\
\hline 3 children & 20 & 15 & 26 & 20 \\
\hline 4 or more children & 13 & 14 & 51 & 15 \\
\hline \multicolumn{5}{|c|}{ Whether lived with both parents until age 16} \\
\hline $\begin{array}{l}\text { Lived with both } \\
\text { parents from birth } \\
\text { to } 16\end{array}$ & 79 & 70 & 66 & 78 \\
\hline $\begin{array}{l}\text { No - parents } \\
\text { divorced, separated } \\
\text { or never together }\end{array}$ & 15 & 19 & 26 & 16 \\
\hline $\begin{array}{l}\text { No - parents } \\
\text { deceased or other } \\
\text { reason }\end{array}$ & 6 & 11 & 8 & 7 \\
\hline \multicolumn{5}{|c|}{ Mental health (measured by GHQ Caseness) } \\
\hline No indication & 85 & 77 & 85 & 84 \\
\hline Some indication & 15 & 23 & 15 & 16 \\
\hline \multicolumn{5}{|l|}{ General health } \\
\hline Excellent & 20 & 16 & 14 & 20 \\
\hline Very good & 38 & 29 & 28 & 36 \\
\hline Good & 29 & 33 & 37 & 30 \\
\hline Fair & 10 & 15 & 15 & 11 \\
\hline Poor & 3 & 7 & 7 & 4 \\
\hline Unweighted base (N) & 5,322 & 773 & 297 & 6,392 \\
\hline
\end{tabular}

All the percentages are weighted.

affiliation being under-represented among fathers with non-resident children. Many of these findings regarding differences by relationship history, economic disadvantage and ethnicity are consistent with earlier literature (discussed above).

The next section examines non-resident fathers' involvement with their children. The analysis draws on data from fathers who have non-resident children only as well as those who have both resident and non-resident children. 
TABLE 2. Non-resident fathers' reported contact and involvement with their non-resident children: fathers with non-resident dependent children $(\mathrm{N}=1,067)$

\begin{tabular}{ll}
\hline & $\%$ \\
\hline How often visits, sees or contacts non-resident children & \\
Never & 13 \\
A few times a year & 11 \\
Once a month or less & 4 \\
Several times a month & 13 \\
About once a week & 21 \\
Several times a week & 23 \\
Almost everyday & 12 \\
Shared care (5o/5o) & 3 \\
Stay on a regular basis & 49 \\
Stay on an irregular basis & 14 \\
In contact but do not stay over & 24 \\
No contact & 13 \\
Yhether non-resident children stay with father regularly & \\
Whether provides money for children support & 68 \\
No & 32 \\
Unweighted base (N) & 1,067 \\
\hline
\end{tabular}

All the percentages are weighted.

\section{Non-resident fathers' involvement with their children}

Table 2 outlines the involvement fathers report between themselves and their non-resident children, focusing on contact and financial support ${ }^{11}$. Previous UK studies have shown that non-resident fathers are subject to over-estimating amounts of contact, and resident parents to under-estimating (Lader, 2008). As such, it should be kept in mind that these figures are based on the fathers' own interpretations of their involvement. It is clear that only a minority of nonresident fathers are not in contact with their children, with nearly four in ten non-resident fathers reporting contact with their children at least several times a week. Furthermore, nearly half of these fathers report that their children stay with them overnight on a regular basis. These findings are consistent with those reported by Haux et al. (2015) who used data from resident mothers.

Over two-thirds of fathers report that they provide money for child support, which is higher than in recent evidence from Maplethorpe et al. (2008) who used data from resident parents and reported that only a third were receiving any child maintenance. This discrepancy may be due to fathers over-reporting and mothers under-reporting.

Although the data on contact uses ordinal categories, which reflect the number of visits rather than parenting time and therefore do not provide a measure of the amount of parenting performed by the non-resident fathers 
TABLE 3. Binary logistic regression model comparing non-residential fathers with at least monthly contact to those with no or rare contact: fathers with non-resident dependent children $(\mathrm{N}=1,067)$

\begin{tabular}{|c|c|c|}
\hline & Odds Ratio & S.E. \\
\hline \multicolumn{3}{|l|}{ Father's characteristics } \\
\hline Age of father & 1.01 & 0.01 \\
\hline \multicolumn{3}{|c|}{ Highest qualification $[\mathrm{ref}=$ degree or higher] } \\
\hline A-level & 1.13 & 0.41 \\
\hline GCSE/other & 0.95 & 0.23 \\
\hline None & 0.67 & 0.18 \\
\hline \multicolumn{3}{|l|}{ Working status [ref=in paid work] } \\
\hline Not in paid work & $* * 0.56$ & 0.11 \\
\hline \multicolumn{3}{|l|}{ Tenure [ref=owns own home/mortgage $]$} \\
\hline Social rent & *0.54 & 0.13 \\
\hline Private rent & $* * 0.53$ & 0.12 \\
\hline Other & 0.96 & 0.57 \\
\hline \multicolumn{3}{|c|}{ Ethnic group of father [ref=White British $]$} \\
\hline Asian & 0.62 & 0.26 \\
\hline Black & 0.78 & 0.23 \\
\hline Other & $* 0.48$ & 0.15 \\
\hline \multicolumn{3}{|c|}{ Current family situation [ref=no children and no partner] } \\
\hline No children but partner & 0.71 & 0.17 \\
\hline Children and a partner & *** 0.40 & 0.08 \\
\hline Children but no partner & 2.93 & 2.22 \\
\hline \multicolumn{3}{|c|}{ Distance lives from child [ref=more than half an hour away] } \\
\hline Less than half an hour away & $* * * 3.18$ & 0.56 \\
\hline
\end{tabular}

$\mathrm{p}<0.001^{* * *}, \mathrm{p}<0.01^{* *}, \mathrm{p}<0.05^{*}$.

All the statistics are weighted.

(Fabricius et al., 2010), these figures provide some insight into their involvement with their non-resident children. To better understand contact, binary logistic regression was used to investigate the factors associated with regular contact and no or rare contact between fathers and their children (frequencies of fathers' characteristics and contact are available in Appendix Table A2).

The results of the binary logistic regression are shown in Table 3 and the findings support much previous US and UK literature in the area of contact post

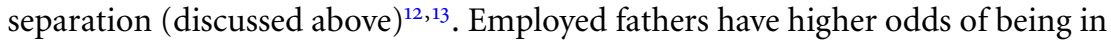
contact than those who are unemployed or economically inactive as do those who are home owners rather than renting their accommodation. This supports findings associating greater income with greater contact, the increased likelihood of contact for these fathers is probably due to the fact that their greater financial resources are used to facilitate and support contact. We found strong evidence of an association between contact and the geographical distance between the child and the father; non-resident fathers who live less than half an hour away have three times higher odds of being in contact than those who live at a greater 
distance. Our findings also show that non-resident fathers see their non-resident children less frequently when they have formed new relationships and had new children; fathers living with children and a partner have lower odds of being in contact than those who are single. However we do not find any support for associations found in earlier literature (discussed above) between contact and age, father's religiosity, ethnicity, education or marriage history. So although some of these factors - ethnicity and marriage history - were associated with the likelihood of being a non-resident father, they are not associated with the frequency of post-separation contact.

The next section explores how characteristics associated with contact are inter-related and identifies 'types' of non-resident fathers.

\section{Involvement types}

Four groups of non-resident fathers have been identified based on their postseparation behaviours and their involvement with their non-resident children. These groups were identified using latent class analysis, a statistical method that identifies subgroups or clusters within data where members within a cluster are relatively homogenous. Figure 1 provides an overview of the typology and outlines the broad characteristics of the four non-resident father groups identified.

Further details of the variables which were used in the latent class analysis and an overview of the characteristics of the father groups are outlined in Table 4. The 'Engaged' fathers emerge as the group which appear to be most involved with their children, they are the most likely to be in contact, have regular overnight stays and provide child support. This group also tend to live close to their nonresident children and are the most likely to be single. The 'Less Engaged' fathers are involved, but have less frequent contact and overnight stays. This group of fathers tend to live within an hour of their non-resident children; however, most live more than 15 minutes away with a third living over an hour away. The 'Disengaged' fathers are those who are least involved with their children post separation, with most not having any contact at all. Most of this group do not provide child support, though three in ten do provide financial support despite the lack of contact. These fathers live a variety of distances from their non-resident children and live in a variety of family situations, though they are the group most likely to be living with a new partner and children. The 'Distance' fathers emerge as a distinct group characterised primarily by the fact that they live over an hour away from their children. These fathers report rare contact with their children and only a minority have overnight stays. However most of these fathers report providing money for child support.

The four groups of non-resident fathers were further explored by examining a range of socio-demographic variables; these are outlined in Table 5. Although we may expect older fathers to be more likely to have the economic resources to 


\begin{tabular}{|c|c|c|c|c|}
\hline & $\begin{array}{l}\text { Engaged } \\
\text { fathers } \\
46 \%\end{array}$ & $\begin{array}{l}\text { Less } \\
\text { Engaged } \\
\text { fathers } \\
28 \%\end{array}$ & $\begin{array}{l}\text { Disengaged } \\
\text { fathers } \\
16 \%\end{array}$ & $\begin{array}{l}\text { Distance } \\
\text { fathers } \\
11 \%\end{array}$ \\
\hline $\begin{array}{l}\text { Contact } \\
\text { with non- } \\
\text { resident } \\
\text { children }\end{array}$ & $\begin{array}{l}\text { At least } \\
\text { weekly } \\
\text { contact }\end{array}$ & $\begin{array}{l}\text { Usually in } \\
\text { contact } \\
\text { once a } \\
\text { week or } \\
\text { once a } \\
\text { month }\end{array}$ & $\begin{array}{l}\text { No contact } \\
\text { or very rare } \\
\text { contact }\end{array}$ & $\begin{array}{l}\text { Rare } \\
\text { contact }\end{array}$ \\
\hline $\begin{array}{l}\text { Overnight } \\
\text { stays with } \\
\text { non- } \\
\text { resident } \\
\text { children }\end{array}$ & $\begin{array}{l}\text { Most have } \\
\text { regular } \\
\text { stays }\end{array}$ & $\begin{array}{l}\text { Mixture but } \\
\text { most have } \\
\text { regular or } \\
\text { irregular } \\
\text { stays }\end{array}$ & $\begin{array}{l}\text { No overnight } \\
\text { stays }\end{array}$ & $\begin{array}{l}\text { Mixture but } \\
\text { most have } \\
\text { no or } \\
\text { irregular } \\
\text { stays }\end{array}$ \\
\hline $\begin{array}{l}\text { Child } \\
\text { support }\end{array}$ & $\begin{array}{l}\text { Most } \\
\text { provide } \\
\text { money for } \\
\text { child } \\
\text { support }\end{array}$ & $\begin{array}{l}\text { Most } \\
\text { provide } \\
\text { money for } \\
\text { child } \\
\text { support }\end{array}$ & $\begin{array}{l}\text { Most do not } \\
\text { provide } \\
\text { money for } \\
\text { child support }\end{array}$ & $\begin{array}{l}\text { Most } \\
\text { provide } \\
\text { money for } \\
\text { child } \\
\text { support }\end{array}$ \\
\hline $\begin{array}{l}\text { Distance } \\
\text { lives from } \\
\text { child }\end{array}$ & $\begin{array}{l}\text { Close - tend } \\
\text { to live less } \\
\text { than } 15 \\
\text { minutes } \\
\text { away }\end{array}$ & $\begin{array}{l}\text { Medium - } \\
\text { tend to live } \\
\text { within an } \\
\text { hour away }\end{array}$ & $\begin{array}{l}\text { Mixture of } \\
\text { distances } \\
\text { lived away } \\
\text { from child }\end{array}$ & $\begin{array}{l}\text { Far away- } \\
\text { all live over } \\
\text { an hour } \\
\text { away }\end{array}$ \\
\hline $\begin{array}{l}\text { Family } \\
\text { residential } \\
\text { status }\end{array}$ & $\begin{array}{l}\text { Most are } \\
\text { single but } \\
\text { some have } \\
\text { new families }\end{array}$ & $\begin{array}{l}\text { Mixture of } \\
\text { family } \\
\text { situations }\end{array}$ & $\begin{array}{l}\text { Mixture of } \\
\text { family } \\
\text { situations }\end{array}$ & $\begin{array}{l}\text { Mixture of } \\
\text { family } \\
\text { situations }\end{array}$ \\
\hline
\end{tabular}

Figure 1. Typology of non-resident fathers

All the percentages are weighted.

Percentages do not add up to 100 due to rounding.

facilitate contact, there is no significant difference in the age profile of the groups; the majority of fathers in all groups are aged 35 or over.

Supporting our findings from the binary logistic regression and previous literature, the more involved father groups, the 'Engaged' fathers and the 'Less Engaged' fathers, appear to be in better economic positions than the 'Disengaged' fathers. The former groups of fathers are more likely to be working full-time, more likely to be home owners, and more likely to have formal education qualifications. The 'Distance' fathers are a more varied group; although they have the highest 
TABLE 4. Overview of father clusters: fathers with non-resident dependent children $(\mathrm{N}=1,042)$

\begin{tabular}{|c|c|c|c|c|}
\hline & $\begin{array}{l}\text { Engaged } \\
\text { fathers } \\
\%\end{array}$ & $\begin{array}{l}\text { Less } \\
\text { Engaged } \\
\text { fathers } \\
\%\end{array}$ & $\begin{array}{l}\text { Disengaged } \\
\text { fathers } \\
\%\end{array}$ & $\begin{array}{l}\text { Distance } \\
\text { fathers } \\
\%\end{array}$ \\
\hline \multicolumn{5}{|l|}{$\begin{array}{l}\text { How often visits, sees or contacts } \\
\text { non-resident children }\end{array}$} \\
\hline Never & o & o & 82 & o \\
\hline A few times a year & 0 & 2 & 14 & 74 \\
\hline Once a month or less & o & 3 & 4 & 26 \\
\hline Several times a month & o & 47 & o & o \\
\hline About once a week & 17 & 48 & o & o \\
\hline Several times a week & 50 & o & o & o \\
\hline Almost everyday & 27 & o & o & o \\
\hline Shared care $(50 / 50)$ & 6 & o & o & o \\
\hline \multicolumn{5}{|l|}{$\begin{array}{l}\text { Whether non-resident children stay } \\
\text { with father regularly }\end{array}$} \\
\hline Stay on a regular basis & 76 & 43 & o & 20 \\
\hline Stay on an irregular basis & 11 & 19 & o & 33 \\
\hline In contact but do not stay over & 13 & 38 & 18 & 47 \\
\hline No contact & 0 & 0 & 82 & o \\
\hline \multicolumn{5}{|l|}{$\begin{array}{l}\text { Whether provides money for children } \\
\text { support }\end{array}$} \\
\hline Yes & 77 & 73 & 30 & 73 \\
\hline No & 23 & 27 & 70 & 27 \\
\hline \multicolumn{5}{|l|}{ Distance lives from child } \\
\hline Less than 15 minutes & 59 & 20 & 33 & o \\
\hline Between $15-60$ minutes & 35 & 48 & 32 & o \\
\hline Over an hour & 7 & 32 & 35 & 100 \\
\hline \multicolumn{5}{|l|}{ Family status } \\
\hline $\begin{array}{l}\text { Partner but no resident } \\
\text { children }\end{array}$ & 21 & 30 & 17 & 34 \\
\hline $\begin{array}{l}\text { Single - no partner or resident } \\
\text { children }\end{array}$ & 59 & 34 & 36 & 41 \\
\hline Partner and resident children & 18 & 32 & 46 & 24 \\
\hline $\begin{array}{l}\text { Resident children but no } \\
\text { partner }\end{array}$ & 2 & 4 & 1 & $>0.5$ \\
\hline Unweighted base (N) & 480 & 282 & 163 & 117 \\
\hline
\end{tabular}

All the percentages are weighted.

proportion of fathers educated to the degree level, they are slightly less likely to work full-time than the more involved father groups.

There are small differences in the ethnicity of the fathers in the 'Engaged', 'Less Engaged' and 'Disengaged' father groups; the most involved father group has a higher proportion of White British fathers. Contrary to earlier research which suggested an association between involvement and religious affiliation, we find that the most involved group also has the highest proportion of fathers who do not regard themselves as belonging to a religious group. Again the 'Distance' 
TABLE 5. Profile of father clusters: fathers with non-resident dependent children $(\mathrm{N}=1,042)$

\begin{tabular}{|c|c|c|c|c|}
\hline & $\begin{array}{l}\text { Engaged } \\
\text { fathers } \\
\%\end{array}$ & $\begin{array}{l}\text { Less Engaged } \\
\text { fathers } \\
\%\end{array}$ & $\begin{array}{l}\text { Disengaged } \\
\text { fathers } \\
\%\end{array}$ & $\begin{array}{l}\text { Distance } \\
\text { fathers } \\
\%\end{array}$ \\
\hline \multicolumn{5}{|l|}{ Age } \\
\hline 16-24 years old & 8 & 3 & 5 & 5 \\
\hline $25-34$ years old & 26 & 23 & 29 & 24 \\
\hline $35-44$ years old & 39 & 43 & 46 & 43 \\
\hline 45 years or more & 27 & 32 & 20 & 28 \\
\hline \multicolumn{5}{|l|}{ Educational attainment } \\
\hline Degree or higher & 20 & 26 & 15 & 32 \\
\hline A level or equivalent & 10 & 8 & 9 & 4 \\
\hline GCSE or other & 47 & 44 & 38 & 38 \\
\hline None & 23 & 21 & 38 & 26 \\
\hline \multicolumn{5}{|l|}{ Working status } \\
\hline Works full-time & 69 & 67 & 48 & 62 \\
\hline Works part-time & 5 & 6 & 5 & 6 \\
\hline Unemployed & 15 & 15 & 26 & 16 \\
\hline Economically inactive & 11 & 12 & 21 & 15 \\
\hline \multicolumn{5}{|l|}{ Tenure } \\
\hline Mortgage/own outright & 55 & 53 & 35 & 35 \\
\hline Social rent & 21 & 23 & 37 & 21 \\
\hline Private rent & 22 & 21 & 27 & 42 \\
\hline Other & 3 & 2 & 2 & 1 \\
\hline \multicolumn{5}{|l|}{ Ethnic group } \\
\hline White British & 90 & 86 & 88 & 62 \\
\hline White other & 3 & 4 & 4 & 20 \\
\hline Asian & 2 & 4 & 3 & 7 \\
\hline Black & 3 & 4 & 4 & 7 \\
\hline Other or unknown & 2 & 2 & 2 & 4 \\
\hline \multicolumn{5}{|l|}{ Religion } \\
\hline None & 70 & 64 & 64 & 52 \\
\hline Christian (inc. Catholic) & 27 & 31 & 31 & 40 \\
\hline Islam & 1 & 3 & 2 & 4 \\
\hline Other & 2 & 2 & 2 & 4 \\
\hline \multicolumn{5}{|l|}{ Marriages (inc. current) } \\
\hline None & 44 & 35 & 43 & 23 \\
\hline One & 42 & 39 & 30 & 55 \\
\hline Two or more & 14 & 26 & 27 & 22 \\
\hline \multicolumn{5}{|l|}{ Cohabitations (inc. current) } \\
\hline None & 39 & 38 & 44 & 43 \\
\hline One & 32 & 25 & 26 & 29 \\
\hline Two & 18 & 21 & 11 & 12 \\
\hline Three or more & 11 & 16 & 19 & 16 \\
\hline \multicolumn{5}{|l|}{ Mental health (measured by GHQ } \\
\hline \multicolumn{5}{|l|}{ Caseness) } \\
\hline No indication & 80 & 80 & 81 & 77 \\
\hline Some indication & 20 & 20 & 19 & 23 \\
\hline \multicolumn{5}{|l|}{ General health } \\
\hline Excellent & 17 & 14 & 11 & 17 \\
\hline Very good & 31 & 27 & 25 & 27 \\
\hline Good & 31 & 38 & 32 & 43 \\
\hline
\end{tabular}


TABLE 5. Continued.

\begin{tabular}{cllll}
\hline & $\begin{array}{l}\text { Engaged } \\
\text { fathers } \\
\%\end{array}$ & $\begin{array}{l}\text { Less Engaged } \\
\text { fathers } \\
\%\end{array}$ & $\begin{array}{l}\text { Disengaged } \\
\text { fathers } \\
\%\end{array}$ & $\begin{array}{l}\text { Distance } \\
\text { fathers } \\
\%\end{array}$ \\
\hline $\begin{array}{c}\text { Fair } \\
\text { Poor }\end{array}$ & 14 & 16 & 20 & 9 \\
Unweighted base $(N)$ & 7 & 5 & 11 & 4 \\
\hline
\end{tabular}

All the percentages are weighted.

fathers emerge as distinct from the other groups with a higher proportion of ethnic minority fathers, particularly those of other White origins, and a higher proportion of fathers with religious affiliation.

Further investigation shows that the 'Distance' group are distinct: a large minority (40 per cent) were not born in the UK, compared with between 9-12 per cent in the other groups (Appendix Table A3). These fathers originated from a range of countries including European countries and India and over threequarters had settled in the UK since 2000. Just under half of all 'Distance' fathers (43 per cent) report that their non-resident children do not live in the UK. Taken together, these findings suggest that 'Distance' fathers are a unique group whose non-resident children are separated by a significant distance within the UK or cross-nationally.

There are no clear patterns when looking at the number of marriages and long-term cohabitations among the father groups, with a range of behaviours within each. The most and least involved groups of fathers, 'Engaged' and 'Disengaged' respectively, have similar proportions of fathers who have never been married, however 'Disengaged' fathers are the most likely to have been married multiple times and 'Engaged' fathers more likely to have been married just once. Although the 'Disengaged' fathers are the most likely to have had three or more cohabiting relationships, they are also the most likely to have had no cohabitations, suggesting a polarisation of behaviours within this group. The 'Distance' fathers are characterised by being the group most likely to have married just once, though they have a range of cohabitation behaviour not dissimilar to the other groups. The large proportion of single marriages in this group may be related to ethnic or religious cultures and norms.

There is no evidence of difference between the groups in terms of mental health, as measured by the GHQ caseness indicator. However with regard to physical health the 'Engaged' fathers are the most likely to report that their health is excellent or very good and the 'Disengaged' fathers the least likely. This suggests that the 'Disengaged' group are not only more economically precarious but also at a disadvantage in terms of health. 


\section{Conclusions}

Our analysis shows that non-resident fathers form a diverse group and that they have a range of involvement with their non-resident children. Examining the characteristics associated with contact, three main themes emerge: economic and social resources, family situation and re-partnering, and location. Nonresident fathers who are in more disadvantaged economic positions have less involvement with their children, which is not surprising given that maintaining and facilitating contact is expensive requiring the need to provide a childappropriate environment in their own home. Non-resident fathers who have re-partnered and have subsequent dependent children living with them have less contact, likely to be related to economic considerations and to the time and emotional resources required by the new family. Finally, frequency of contact is related to the distance the child lives from the father, which may be linked to other factors such as economic concerns and their family situation.

It is clear from the typology of non-resident fathers that, typically, the 'Engaged' fathers are well placed to maintain involvement with their non-resident children. Most are employed and home owners and, as most are single, they have less of the financial, time and emotional pressures of partnered non-resident fathers. Although we do not know about the relationships which any of the groups of separated fathers have with the resident mothers (a powerful factor in post-separation involvement) the 'Engaged' fathers are arguably the least likely to be affected by the legal and policy changes. They are already involved with their children and they are the group most likely to have the resources to facilitate shared care, make child support payments and pay legal fees. It is important that any new legislation does not hinder involvement, where levels are already high.

The 'Less Engaged' fathers share similarities with the 'Engaged' fathers; both groups have similar proportions of fathers in employment, home owners and fathers educated to degree level. However 'Less Engaged' fathers have more pressures on their resources as they are more likely to have new families. Although the legal and policy changes aim to promote involvement following separation, with some services having been funded to this end, it is unlikely that these services will work to alleviate the demands on resources which this group experience.

The 'Disengaged' and 'Distance' fathers pose the greatest challenges for policy. The 'Disengaged' fathers have very limited involvement with their nonresident children; the majority have no contact, and only a minority are providing child support. Nearly half of these fathers are unemployed or economically inactive. The legal and policy changes aim to increase involvement and 'family based' arrangements but, in the absence of any father-child relationship and a lack of economic resources, it seems highly unlikely that, notwithstanding the help and support initiatives, these changes will be successful. Furthermore, by making access to legal and statutory services more difficult it is possible that the changes could exacerbate existing problems as avenues for redress are narrowed, 
for example if child support is not paid. To increase involvement with nonresident children among this father group, not only would services have to be made available which would re-engage these fathers but also this group would need to be supported financially to be able to establish and maintain contact. Such support is unlikely in the context of austerity cuts; in fact recent analysis (Institute for Fiscal Studies, 2015) predicts a decline in fiscal support for lowincome families with children in the UK.

The particular situation of 'Distance' fathers poses unique challenges. Not only does this group face many of the barriers experienced by the other groups but these fathers are also geographically separated from their children placing a practical restriction on their direct involvement, in particular the possibility of day-to-day parenting. This restriction is worse for those fathers whose children live outside the UK. Although the 'Distance' fathers are only a minority of the population of non-resident fathers, in order to promote and support involvement between these fathers and their children help and support services which address the particular needs of this group need to be made available. These are likely to vary according to whether the non-resident children live in the UK or elsewhere. In this context global legislation, such as the United Nations Convention on the Rights of the Child (UNICEF, 1989) or the Hague Convention supporting conciliatory post-separation adjudication become relevant (Hague Convention, 1993). The principle that children of separated parents have the right to stay in contact with both parents, unless this may be harmful to them, is enshrined in Article 9 of The United Nations Convention on the Rights of the Child (UNICEF, 1989). As the mobility of populations increases through globalisation, it is clear that addressing children's access to parents across national borders will become more pressing. Similarly within supra-governmental bodies such as the EU, more consideration of nation state obligations to children of separated parents will be needed.

\section{Methodological limitations}

The analysis presented in this paper has a number of methodological limitations, primarily related to the data available in the Understanding Society survey. Firstly, the data analysed is cross-sectional (it all comes from Wave 1) and therefore there is no information about whether the behaviours and characteristics identified show continuity or change over time. As noted above, longitudinal analysis of non-resident fathers using Understanding Society data was explored but was not possible due to high levels of attrition among non-resident fathers at later waves of the survey. Secondly, there is no information on parental involvement and activities before separation; as such we cannot identify pre-separation antecedents of post-separation family life. Thirdly, the questions ask about contact with nonresident children under 16 years generally and do not distinguish by age, gender or number of non-resident children. This is problematic because we know from 
earlier studies that parenting varies both in relation to specific children within the family but also as children grow up. Furthermore, the measures of contact, frequency of contact and financial support available in the survey are rather basic, providing only an overview of any type of familial contact or financial provision. Finally, some of the variables which are known to be associated with non-residential father involvement are not available such as the length of time since separation or the previous and current relationship quality between the separated parents.

However, our 'father-centric' analysis provides one of the first broad accounts of non-residential fatherhood in early millennium UK and informs policy developments around separated families. It contributes to extending the vision of men's engagement in family life beyond a focus on fathers who are coresident, married and presumed biological. Further research is needed to unpick the diversity among non-resident fathers in the UK and to evaluate how the recent policy and legal changes will affect the different groups of fathers we have identified over time. Of particular import would be research which can utilise information not only about the non-resident father but also his children and the resident parent and research which can track non-resident fathers and their complex families longitudinally. In order to facilitate this research, more recognition needs to be given to the important position which non-resident fathers play in their children's lives, and consequently greater investment needs to be made to collect robust and representative data about this group of fathers.

\section{Acknowledgement}

This research was funded by the UK Economic and Social Research Council as part of the Secondary Data Analysis Initiative Phase 1 ES/Koo3739/1. We would like to thank the UK Data Service for making the data available to us, anonymous referees, and participants at various seminars and workshops for useful comments that have helped in the development of the paper.

\section{Notes}

1 For example http://www.thetimes.co.uk/tto/opinion/leaders/article3787773.ece.

2 Child maintenance and child support are terms which are used interchangeably.

3 Exceptions, where financial assistance will be given, include cases of domestic violence, children at risk of abuse and cases where there is a risk of a breach of civil rights.

4 All data presented is weighted to be representative of the UK population and, where applicable, other complex survey design variables have been used.

5 This analysis has been performed using Stata version 12.0.

6 The significance of associations in this and similar analyses was tested based on an F-test in a series of binary logistic regression models, where each explanatory variable was included individually.

7 Using LatentGOLD 4.0 software.

8 This includes men who have only non-resident children (3 per cent) and men who have both resident and non-resident children ( 1 per cent) - due to rounding these figures add up to 5 per cent. 
9 In total 20,340,700 men aged 16-64 are estimated to have been living in the UK in mid-2012 (Office for National Statistics, 2013). From this we calculated the number of men who report non-resident children. The 95 per cent confidence interval is from 915,000 to 1,037,000. Estimates are rounded to the nearest 1000.

10 All findings discussed are from bi-variate analysis so do not control for other confounding variables. However exploratory multi-variate analysis (not shown) supported the three broad categories of differences between resident and non-resident fathers shown here.

11 Unlike other studies, questions relating to contact are not asked in relation to a specific focal child. The questions are asked about all non-resident children aged under 16. Furthermore the characteristics of the non-resident children are not known.

12 Despite associations with contact found in other literature, no data is collected in the survey about the mother (the resident parent), the relationship between the separated parents or any characteristics of the children such as age or gender.

13 Factors which were significant in bivariate analysis but not significant when controlling for other factors have not been included in the model (whether the father has ever been married, religiosity and number of bedrooms in the house).

\section{References}

Akaike, H. (1974), "A new look at the statistical model identification" (PDF), IEEE Transactions on Automatic Control 19 (6): 716-723, doi:10.1109/TAC.1974.1100705, MR 0423716.

Amato, P. R. and Dorius, C. (2010), 'Fathers, children and divorce', in M. E. Lamb (ed.) The role of the father in child development, Hoboken, NJ: John Wiley \& Sons.

Amato, P. R., Meyers, C. E. and Emery, R. E. (2009), 'Changes in nonresident father-child contact from 1976 to 2002', Family Relations, 58: 1, 41-53.

Bradshaw, J., Stimson, C., Skinner, C. and Williams, J. (1999), Absent Fathers?, Routledge: London.

Bryson, C., Skipp, A., Allbeson, J., Poole, E., Ireland, E. and Marsh, V. (2013), “Kids Aren't Free": The child maintenance arrangements of single parents on benefit, London: Nuffield Foundation.

Cabrera, N. and Tamis-LeMonda, C. (2013), Handbook of Father Involvement: Multidisciplinary Perspectives, New York: Taylor and Francis.

Centre for Social Justice (2013), Fractured Families: Why Stability Matters.

Cheadle, J., Amato, P. and King, V. (2010), 'Patterns of Nonresident Father Involvement', Demography, 47: 205-226.

Children and Families Act (2014), http://www.legislation.gov.uk/ukpga/2014/6/contents

Department for Work and Pensions (2010), Equality Impact Assessment, Strengthening Families, promoting parental responsibility: the future of child maintenance.

Department for Work and Pensions (2012), Separated families and child maintenance arrangements, Great Britain 2011.

Department for Work and Pensions (2014), Child Support Agency Quarterly Summary of Statistics for Great Britain, September 2014 https://www.gov.uk/government/statistics/ child-support-agency-quarterly-summary-statistics-september-2014

Eggebeen, D. J. and Knoester, C. (2001), 'Does Fatherhood Matter for Men?', Journal of Marriage and Family, 63: 2, 381-393.

Fabricius, W. V., Braver, S. L., Diaz, P. and Velez, C. E. (2010), 'Custody and parenting time: Links to family relationships and well-being after divorce', in M. E. Lamb (ed.) The role of the father in child development, Hoboken, NJ: John Wiley \& Sons.

Fatherhood Institute (2013), FI Calls on Government to Scrap Bedroom Tax for Separated Fathers (press release), http://www.fatherhoodinstitute.org/2013/fi-calls-ongovernment-to-scrap-bedroom-tax-for-separated-fathers/.

Fehlberg, B., Smyth, B., Maclean, M. and Roberts, C. (2011), 'Caring for children after parental separation: Would legislation for shared parenting time help children?', Family 
Policy Briefing 7, Department of Social Policy and Intervention, University of Oxford: Oxford.

Garfinkel, I., McLanahan, S. S. and Hanson, T. L. (1998), A patchwork portrait of nonresident fathers. Fathers under fire: The revolution in child support enforcement, 50.

Hague Convention (1993), Convention of 29 May 1993 on Protection of Children and Co-operation in Respect of Intercountry Adoption, http://www.hcch.net/index en.php?act=conventions.listing

Haux, T., Platt, L. and Rosenberg, R. (2015), Parenting and post-separation contact: what are the links? LSE: CASE working Paper 189.

Henz, U. (2014), 'Long-term trends of men's co-residence with children in England and Wales', Demographic Research, 30: 1, 671-702.

Hernandez, D. J. and Brandon, P. D. (2002), 'Who are the fathers of today?' in C. S. TamisLeMonda and N. Cabrera (eds.) Handbook of father involvement: Multidisciplinary perspectives, Mahwah, NJ: Erlbaum.

Hetherington, E. M. (2003), 'Intimate pathways: Changing patterns in close personal relationships across time', Family Relations, 52: 318-331.

Institute for Fiscal Studies (2015), Benefit cuts: where might they come from? London: IFS http://www.ifs.org.uk/publications/7762

Kiernan, K. (1997), 'Becoming a young parent: a longitudinal study of associated factors', British Journal of Sociology, 48: 3, 406-428.

Kiernan, K. (2006), 'Non-residential Fatherhood and Child Involvement: Evidence from the Millennium Cohort Study', Journal of Social Policy, 35: 4, 651-669.

Kiernan, K. and Smith, K. (2003), 'Unmarried Parenthood: New Insights from the Millennium Cohort Study', Population Trends, 114: 26-33.

King, V. (2003), 'The influence of religion on fathers' relationships with their children', Journal of Marriage and Family, 65: 2, 382-395.

Lader, D. (2008), 'Non-resident parental contact, 2007/8', Omnibus Survey report. Newport: Office for National Statistics.

Lamb, M. E., Pleck, J. H., Charnov, E. L. \& Levine, J. A. (1985), 'Paternal behaviour in humans', American Zoologist, 25: 883-894.

Maclean, M. and Eekelaar, J. (1997), The Parental Obligation: A study of parenthood across households, Hart Publishing Limited: Oxford.

Manning, W. D., Stewart, S. D. and Smock, P. J. (2003), 'The complexity of fathers' parenting responsibilities and involvement with nonresident children', Journal of Family Issues, 24: $5,645-667$.

Maplethorpe, N., Chanfreau, J., Philo, D. and Tait, C. (2008), Families with children in Britain: findings from the Families and Children Survey (FACS), Department for Work and Pensions Research Report 656, London: Stationary Office.

Morris, S. (2007), Child support awards in Britain: an analysis of data from the families and children study, Discussion Paper, Centre for Analysis of Social Exclusion, London School of Economics and Political Science.

O’Brien, M. (2011), 'Fathers in challenging family contexts: a need for engagement', Men in Families and Family Policy in a Changing World Report, New York: United Nations Department of Economic and Social Affairs.

Office for National Statistics (2013), Mid-2012 Population Estimates: United Kingdom; estimated resident population by single year of age and sex, London: ONS.

Organisation for Economic Cooperation and Development (2010), OECD Family Database, 'Supplement SF3.1: Marriage and divorce rates', OECD-Social Policy Division Directorate of Employment, Labour and Social Affairs.

Rendall, M., Clarke, L., Peters, E., Ranjit, N. and Verropoulou, G. (1999), 'Incomplete Reporting of Men's Fertility in the United States and Britain: A Research Note', Demography, 36: 135144 .

Schwarz, Gideon E. (1978), "Estimating the dimension of a model", Annals of Statistics 6 (2): 461-464, doi:10.1214/aos/1176344136, MR 468014 
Scott, M., Peterson, K., Ikramullah, E. and Manlove, J. (2013), 'Multiple partner fertility among nonresident fathers', in N. Cabrera and C. Tamis-LeMonda (eds.) Handbook of Father Involvement: Multidisciplinary Perspectives, New York: Taylor and Francis.

Simpson, B., McCarthy, P., \& Walker, J. (1995), Being There: Fathers After Divorce: An Exploration of Post-divorce Fathering. Relate Centre for Family Studies, University of Newcastle upon Tyne.

Skinner, C. (2013), 'Child maintenance reforms: understanding fathers' expressive agency and the power of reciprocity', International Journal of Law, Policy and the Family, $27 \mathrm{~L} 2,242-265$.

Sobolewski, J. and King, V. (2005), 'The Importance of the Coparental Relationship for Nonresident Fathers' Ties to Children', Journal of Marriage and Family, 67: 5, 1196-1212.

Sorenson, E. (1997), 'A National Profile of Nonresident Fathers and Their Ability to Pay Child Support', Journal of Marriage and Family, 59: 785-797.

Stephens, L. S. (1996), 'Will Johnny see daddy this week? An empirical test of three theoretical perspectives of postdivorce contact', Journal of Family Issues, 17: 4, 466-494.

Stykes, J. B., Manning, W. D. and Brown, S. L. (2013), 'Nonresident Fathers and Formal Child Support: Evidence from the CPS, NSFG, and SIPP', Demographic Research, 29: 46, 12991330.

Swiss, L. and Le Bourdais, C. (2009), 'Father-Child Contact After Separation: The Influence of Living Arrangements', Journal of Family Issues, 30: 5, 623-652.

Unicef (1989), Convention on the Rights of the Child.

University of London. Institute of Education. Centre for Longitudinal Studies. (2014). National Child Development Study: Childhood Data, Sweeps 0-3, 1958-1974. [data collection]. 3rd Edition. UK Data Service. SN: 5565.

University of London. Institute of Education. Centre for Longitudinal Studies. (2012). Millennium Cohort Study: First Survey, 2001-2003. [data collection]. 11th Edition. UK Data Service. SN: 4683 .

Zhang, Z. and Hayward, M. (2006), 'Gender, the marital life course, and cardiovascular disease in late midlife', Journal of Marriage and Family, 68: 639-657.

\section{Appendix}

TABLE A1. Characteristics of non-resident father with contact and rare or no contact: fathers with non-resident dependent children $(\mathrm{N}=1,067)$

\begin{tabular}{llll}
\hline & $\begin{array}{l}\text { No or rare } \\
\text { contact } \\
\%\end{array}$ & $\begin{array}{l}\text { Contact } \\
\%\end{array}$ & $\begin{array}{l}\text { All non- } \\
\text { resident fathers } \\
\%\end{array}$ \\
\hline Age of father & & & \\
$16-24$ years old & 6 & 6 & 6 \\
$25-34$ years old & 26 & 25 & 25 \\
35-44 years old & 46 & 40 & 42 \\
45 years or more & 22 & 29 & 27 \\
Educational attainment & 22 & 22 & 22 \\
Degree or higher & 6 & 9 & 8 \\
A level & 37 & 46 & 44 \\
GCSE/other & 34 & 23 & 25 \\
None & & & 64 \\
Employment status & 53 & 68 & 6 \\
Works full-time & 5 & 6 & 17 \\
Works part-time & 23 & 15 & 13 \\
Unemployed & 19 & 12 & \\
Economically inactive & & & \\
\hline
\end{tabular}


TABLE A1. Continued.

\begin{tabular}{|c|c|c|c|}
\hline & $\begin{array}{l}\text { No or rare } \\
\text { contact } \\
\%\end{array}$ & $\begin{array}{l}\text { Contact } \\
\%\end{array}$ & $\begin{array}{l}\text { All non-res } \\
\text { fathers } \\
\%\end{array}$ \\
\hline \multicolumn{4}{|l|}{ Tenure } \\
\hline Mortgage/own outright & 32 & 54 & 49 \\
\hline Social rent & 33 & 22 & 24 \\
\hline Private rent & 33 & 22 & 25 \\
\hline Other & 2 & 2 & 2 \\
\hline \multicolumn{4}{|l|}{ Number of bedrooms } \\
\hline 1 or no bedrooms & 18 & 10 & 12 \\
\hline 2 bedrooms & 28 & 29 & 28 \\
\hline 3 or more bedrooms & 54 & 61 & 60 \\
\hline \multicolumn{4}{|l|}{ Ethnicity } \\
\hline White - British & 76 & 88 & 85 \\
\hline White - other & 10 & 3 & 5 \\
\hline Mixed & 1 & 1 & 1 \\
\hline Asian & 5 & 3 & 3 \\
\hline Black & 5 & 4 & 4 \\
\hline Other & 2 & 1 & 1 \\
\hline Unknown & o & $>0.5$ & $>0.5$ \\
\hline \multicolumn{4}{|l|}{ Religious affiliation } \\
\hline No religion & 61 & 67 & 65 \\
\hline Christian (including Catholic) & 32 & 29 & 30 \\
\hline Islam/Muslim & 4 & 2 & 2 \\
\hline Hindu & o & o & o \\
\hline Sikh & 1 & o & o \\
\hline Other & 2 & 1 & 2 \\
\hline \multicolumn{4}{|l|}{ Whether they have ever been married } \\
\hline No & 38 & 39 & 39 \\
\hline Yes & 62 & 61 & 61 \\
\hline \multicolumn{4}{|l|}{ Current family situation } \\
\hline No children and no partner & 37 & 49 & 47 \\
\hline No children but partner & 24 & 25 & 24 \\
\hline Children and a partner & 37 & 24 & 27 \\
\hline Children but no partner & 1 & 3 & 2 \\
\hline \multicolumn{4}{|l|}{ Distance lives from child } \\
\hline Half an hour or less & 30 & 68 & 59 \\
\hline More than half an hour & 70 & 32 & 41 \\
\hline \multicolumn{4}{|l|}{ Mental health (measured by GHQ } \\
\hline Caseness) & & & \\
\hline No indication & 78 & 80 & 79 \\
\hline Some indication & 22 & 20 & 21 \\
\hline \multicolumn{4}{|l|}{ General health } \\
\hline Excellent & 13 & 16 & 15 \\
\hline Very good & 26 & 30 & 29 \\
\hline Good & 36 & 34 & 34 \\
\hline Fair & 16 & 15 & 15 \\
\hline Poor & 9 & 6 & 7 \\
\hline
\end{tabular}


TABLE A1. Continued.

\begin{tabular}{clll}
\hline & $\begin{array}{l}\text { No or rare } \\
\text { contact } \\
\%\end{array}$ & $\begin{array}{l}\text { Contact } \\
\%\end{array}$ & $\begin{array}{l}\text { All non-res } \\
\text { fathers } \\
\%\end{array}$ \\
\hline Closeness with child & & & \\
Very close & 22 & 73 & 61 \\
Quite close & 13 & 22 & 20 \\
Not very close & 19 & 5 & 8 \\
Not at all close & 46 & 0 & 11 \\
Unweighted base $(N)$ & 258 & 809 & 1,067 \\
\hline
\end{tabular}

All the percentages are weighted.

TABLE A2. Overview of variables used in Latent Class Analysis: fathers with non-resident dependent children $(\mathrm{N}=1,070)$

How often visits, sees or contacts non-resident children

Never

A few times a year

Once a month or less

Several times a month

About once a week

Several times a week 23

Almost everyday $\quad 12$

Shared care (50/50) 3

Whether non-resident children stay with father regularly

Stay on a regular basis

Stay on an irregular basis

In contact but do not stay over $\quad 24$

$\begin{array}{ll}\text { No contact } & 13\end{array}$

Whether provides money for children support

Yes

No

Distance lives from child

Less than 15 minutes

Between 15 minutes and an hour $\quad 34$

$\begin{array}{ll}\text { Over an hour } & 29\end{array}$

Family residential status

Partner but no resident children 24

Single - no partner or resident children $\quad 46$

Partner and resident children $\quad 27$

Resident children but no partner 2

$\begin{array}{ll}\text { Unweighted base }(N) & 1,070\end{array}$

All the percentages are weighted. 
TABLE A3. Non-resident fathers' origin and location of child: fathers with non-resident dependent children $(\mathrm{N}=1,042)$

\begin{tabular}{|c|c|c|c|c|}
\hline & $\begin{array}{l}\text { Engaged } \\
\text { fathers } \\
\%\end{array}$ & $\begin{array}{l}\text { Less Engaged } \\
\text { fathers } \\
\%\end{array}$ & $\begin{array}{l}\text { Disengaged } \\
\text { fathers } \\
\%\end{array}$ & $\begin{array}{l}\text { Distance } \\
\text { fathers } \\
\%\end{array}$ \\
\hline \multicolumn{5}{|l|}{ Whether born in the UK } \\
\hline Yes & 91 & 88 & 89 & 60 \\
\hline No & 9 & 12 & 11 & 40 \\
\hline \multicolumn{5}{|l|}{ Country born in } \\
\hline UK & 91 & 88 & 89 & 60 \\
\hline Other European country & 3 & 1 & 3 & 10 \\
\hline Australia or New Zealand & $>0.5$ & 1 & o & o \\
\hline USA or Canada & 1 & 1 & $\mathrm{o}$ & 1 \\
\hline $\begin{array}{l}\text { India, Pakistan, Bangladesh } \\
\text { or Sri Lanka }\end{array}$ & 1 & 1 & 2 & 4 \\
\hline Africa & 1 & 1 & $>0.5$ & 4 \\
\hline Caribbean & $>0.5$ & 1 & 1 & o \\
\hline Other country & 3 & 6 & 5 & 20 \\
\hline \multicolumn{5}{|l|}{ Year came to live in the UK } \\
\hline 1950 to 1959 & $>0.5$ & 1 & 1 & 2 \\
\hline 1960 to 1969 & 2 & 1 & 1 & 2 \\
\hline 1970 to 1979 & 3 & 1 & 1 & 1 \\
\hline 1980 to 1989 & 2 & 2 & 1 & 2 \\
\hline 1990 to 1999 & 1 & 3 & 1 & 2 \\
\hline 2000 to 2009 & 2 & 3 & 7 & 31 \\
\hline Since 2010 & $>0.5$ & 2 & $>0.5$ & $>0.5$ \\
\hline Born in the UK & 91 & 88 & 89 & 60 \\
\hline \multicolumn{5}{|l|}{ Whether child lives in the UK } \\
\hline Yes & 98 & 92 & 86 & 57 \\
\hline No & 2 & 8 & 14 & 43 \\
\hline Unweighted base $(N)$ & 480 & 282 & 163 & 117 \\
\hline
\end{tabular}

All the percentages are weighted. 


\begin{tabular}{|c|c|c|}
\hline Measure & Survey question/s & Coding \\
\hline $\begin{array}{l}\text { Non- } \\
\text { resident } \\
\text { fatherhood }\end{array}$ & $\begin{array}{l}\text { Lvrel } \\
\text { We now have a few questions } \\
\text { about contact you have with family } \\
\text { members not living here with you. } \\
\text { Excluding relatives who are living } \\
\text { in this household with you at the } \\
\text { moment, can you look at this card } \\
\text { and tell me which of these types of } \\
\text { relatives you have alive at the } \\
\text { moment? } \\
\text { DO NOT INCLUDE RELATIVES } \\
\text { LIVING IN THIS HOUSEHOLD } \\
1 \text { Mother } \\
2 \text { Father } \\
3 \text { Son(s)/daughter(s) } \\
4 \text { Brothers/sisters } \\
5 \text { Grandchildren } \\
6 \text { Grandparents } \\
7 \text { Great Grandchildren } \\
8 \text { Great Grandparents } \\
96 \text { None of these } \\
\text { Ohch16 } \\
\text { Are any of your children living } \\
\text { outside the household aged under } \\
16 ? \\
1 \text { Yes, all under } 16 \\
2 \text { Yes, at least one under } 16 \\
3 \text { None under } 16\end{array}$ & $\begin{array}{l}\text { Fathers with non-resident } \\
\text { children only are defined in } \\
\text { this paper as those male } \\
\text { respondents who indicated at } \\
\text { Lvrel and Ohch16 that they } \\
\text { had at least one non-resident } \\
\text { child aged under } 16 \text { and } \\
\text { based on the household } \\
\text { composition data were not } \\
\text { living with a child of } \\
\text { dependent age at the time of } \\
\text { interview (DWP definition of } \\
\text { dependency) } \\
\text { Fathers with resident children } \\
\text { only are defined in this paper } \\
\text { as those male respondents } \\
\text { who indicated at Lvrel and } \\
\text { Ohch16 that they did not } \\
\text { have a non-resident child } \\
\text { aged under } 16 \text { and based on } \\
\text { the household composition } \\
\text { data were currently living } \\
\text { with at least one child of } \\
\text { dependent age at the time of } \\
\text { interview } \\
\text { Fathers with both resident } \\
\text { and non-resident children } \\
\text { indicated at Lvrel and } \\
\text { Ohch16 that they had at least } \\
\text { one non-resident child aged } \\
\text { under } 16 \text { and were currently } \\
\text { living with a child of } \\
\text { dependent age }\end{array}$ \\
\hline $\begin{array}{l}\text { Contact } \\
\text { with non- } \\
\text { resident } \\
\text { child/ren }\end{array}$ & $\begin{array}{l}\text { Seekid } \\
\text { Can you tell me how often you visit, } \\
\text { see or contact your child(ren) under } \\
16 \text { living outside the household? } \\
1 \text { Never } \\
2 \text { A few times a year } \\
3 \text { Once a month or less } \\
4 \text { Several times a month } \\
5 \text { About once a week } \\
6 \text { Several times a week } \\
7 \text { Almost everyday } \\
8 \text { Shared care } 50 / 50^{\star}\end{array}$ & $\begin{array}{l}\text { The logistic regression model } \\
\text { presented in Table } 3 \text { defines } \\
\text { 'no or rare contact' as those } \\
\text { who answered } 1 \text { or } 2 \text { at } \\
\text { Seekid. } \\
\text { The logistic regression model } \\
\text { presented in Table } 3 \text { defines } \\
\text { 'contact' as those who } \\
\text { answered } 3,4,5,6,7 \text { or } 8 \text { at } \\
\text { Seekid. }\end{array}$ \\
\hline $\begin{array}{l}\text { Financial } \\
\text { support for } \\
\text { non- } \\
\text { resident } \\
\text { child/ren }\end{array}$ & $\begin{array}{l}\text { Kidspt } \\
\text { Thinking about your children aged } \\
\text { under } 16 \text { who are not living with you } \\
\text { here, do you send or give money for } \\
\text { child support? } \\
1 \text { Yes } \\
2 \text { No }\end{array}$ & \\
\hline
\end{tabular}

*Understanding Society starts with a Household Questionnaire which collects

details of all individuals who usually live at the address. For children who reside at the household half of the time (50/50 care) it is up to the main household

respondent to decide how the child's residence is defined. Therefore there will not be consistency in the responses with regards to 50/50 care; some respondents would classify the children as resident and some as non-resident.

Appendix Figure 1A. Key Measures from Understanding Society Wave 1 - Main adult questionnaire 